\title{
Randomized noninferiority clinical trial evaluating 3 commercial dry cow mastitis preparations: II. Cow health and performance in early lactation
}

\author{
A. G. Arruda, ${ }^{*}$ S. Godden, ${ }^{* 1}$ P. Rapnicki, ${ }^{*}$ P. Gorden, $\dagger$ L. Timms, $†$ S. S. Aly, $\ddagger \S$ T. W. Lehenbauer, $\ddagger \S$ \\ and J. Champagneł§ \\ *Department of Veterinary Population Medicine, University of Minnesota, Saint Paul 55108 \\ †Veterinary Diagnostic and Production Animal Medicine, lowa State University, Ames 50011 \\ ¥Veterinary Medicine Teaching and Research Center, Tulare 93274 \\ §Department of Population Health and Reproduction, University of California, Davis 95616
}

\begin{abstract}
The objective of this randomized noninferiority clinical trial was to compare the effect of treatment with 3 different dry cow therapy formulations at dryoff on cow-level health and production parameters in the first $100 \mathrm{~d}$ in milk (DIM) in the subsequent lactation, including 305-d mature-equivalent (305ME) milk production, linear score (LS), risk for the cow experiencing a clinical mastitis event, risk for culling or death, and risk for pregnancy by 100 DIM. A total of 1,091 cows from 6 commercial dairy herds in 4 states (California, Iowa, Minnesota, and Wisconsin) were randomly assigned at dry-off to receive treatment with 1 of 3 commercial products: Quartermaster (QT; Zoetis Animal Health, Madison, NJ), Spectramast DC (SP; Zoetis Animal Health) or ToMorrow Dry Cow (TM; Boehringer Ingelheim Vetmedica Inc., St Joseph, MO). All clinical mastitis, pregnancy, culling, and death events occurring in the first 100 DIM were recorded by farm staff using an on-farm electronic record-keeping system. Dairy Herd Improvement Association test-day records of milk production and milk component testing were retrieved electronically. Mixed linear regression analysis was used to describe the effect of treatment on 305ME milk production and LS recorded on the last Dairy Herd Improvement Association test day before 100 DIM. Cox proportional hazards regression analysis was used to describe the effect of treatment on risk for experiencing a case of clinical mastitis, risk for leaving the herd, and risk for pregnancy between calving and 100 DIM. Results showed no effect of treatment on adjusted mean $305 \mathrm{ME}$ milk production $(\mathrm{QT}=11,759 \mathrm{~kg}, \mathrm{SP}=11,574 \mathrm{~kg}$, and $\mathrm{TM}=11,761 \mathrm{~kg})$ or adjusted mean $\mathrm{LS}(\mathrm{QT}=1.8, \mathrm{SP}$ $=1.9$, and $\mathrm{TM}=1.6$ ) on the last test day before 100 DIM. Similarly, no effect of treatment was observed
\end{abstract}

Received February 18, 2013.

Accepted July 6, 2013.

${ }^{1}$ Corresponding author: godde002@umn.edu on risk for a clinical mastitis event (QT $=14.8 \%, \mathrm{SP}$ $=12.7 \%$, and $\mathrm{TM}=15.0 \%$ ), risk for leaving the herd $(\mathrm{QT}=7.5 \%, \mathrm{SP}=9.2 \%$, and $\mathrm{TM}=10.3 \%)$, or risk for pregnancy $(\mathrm{QT}=31.5 \%, \mathrm{SP}=26.1 \%$, and $\mathrm{TM}=$ $26.9 \%$ ) between calving and 100 DIM.

Key words: dry cow mastitis, dry cow therapy, milk production, and health

\section{INTRODUCTION}

Dry cow mastitis involves IMI that persist through the dry period from the previous lactation or new IMI acquired during the dry period. North American studies estimate that between 13 and $35 \%$ of quarters are subclinically infected at dry-off (Oliver and Mitchell, 1983; Godden et al., 2003; Pantoja et al., 2009), and between 8 and $25 \%$ of quarters develop a new IMI during the dry period (Godden et al., 2003; Cook et al., 2005; Arruda et al., 2013). North American studies reporting the prevalence of IMI at calving at the cow level are relatively few. However, in one recent study of 2 Florida dairy herds, isolates of mastitis-causing bacteria were obtained from $12.9 \%$ of composite samples collected at calving from 179 cows (Pinedo et al., 2012). The presence of subclinical IMI at calving is associated with several economically important negative consequences in the subsequent lactation, including elevated SCC, increased risk for clinical mastitis, impaired milk production, impaired reproductive performance, and increased risk for death or culling (Dohoo and Martin, 1984; Milian-Suazo et al., 1989; Schrick et al., 2001; Green et al., 2005; USDA-APHIS, 2011). Clearly, effective control strategies are needed to prevent and control dry cow mastitis and to mitigate its negative consequences.

Blanket dry cow therapy (DCT), defined as the infusion of all quarters of all cows at dry-off with a longacting intramammary antibiotic, is recommended by the National Mastitis Council (NMC, 1999), both for the purpose of curing existing subclinical infections and preventing new infections that could be acquired dur- 
ing the early dry period. This practice has been proven to reduce the prevalence of IMI at calving, thereby reducing the aforementioned associated detrimental consequences in the subsequent lactation. Dairy producers generally select DCT products based on some combination of factors including product efficacy, required dry period length, required milk withhold postcalving, and cost. Although all commercially available Food and Drug Administration-licensed DCT products have demonstrated efficacy compared with a negative control, studies comparing the relative efficacy of DCT products are relatively limited, and often conducted in regions of the world using DCT products not available in the United States. As one example, in one recent United Kingdom study of 489 cows, animals were treated with a broad-spectrum antibiotic cefquinome, a combination treatment comprising a narrow-spectrum antibiotic cloxacillin and an internal teat sealant, or a narrow-spectrum antibiotic cloxacillin alone (Bradley et al., 2011). Those authors reported no difference among treatment groups in terms of cure of IMI caused by major pathogens. However, quarters in both the combination and cefquinome-treated groups were more likely to be free of a major pathogen or enterobacterial pathogen postcalving. Also, cefquinome-treated quarters were less likely to develop clinical mastitis than cloxacillin-treated quarters in the first 100 DIM. Another recent noninferiority study conducted in New Zealand reported that a novel cephalonium formulation of antibiotic DCT was noninferior compared with a reference cephalonium DCT formulation for cure of existing IMI and prevention of new IMI (McDougall, 2010). The fact that the products evaluated in both of the aforementioned studies are not commercially available in the United States supports the need for the evaluation of the relative efficacy of Food and Drug Administration-approved DCT in the United States.

Three commonly used dry cow products in the United States include Quartermaster (QT; Zoetis Animal Health, Madison, NJ), Spectramast DC (SP; Zoetis Animal Health) and ToMorrow Dry Cow (TM; Boehringer Ingelheim Vetmedica Inc., St Joseph, MO). Quartermaster is formulated to contain 1,000,000 IU of procaine penicillin $\mathrm{G}$ and $1 \mathrm{~g}$ of dihydrostreptomycin. Spectramast DC and TM are formulated to contain 500 $\mathrm{mg}$ of ceftiofur and $300 \mathrm{mg}$ of cephapirin, respectively. One very recent study reported that treatment with SP resulted in a lower incidence of clinical mastitis and a lower prevalence of elevated linear score (LS) during the first 60 DIM (Pinedo et al., 2012). However, that study was limited to the study of 2 DCT products on 2 dairy herds located in the state of Florida.

In an earlier companion paper, a randomized noninferiority clinical trial evaluating quarter-level outcomes reported no difference among SP, QT, or TM, with respect to risk for a bacteriological cure in the quarter over the dry period, risk for the quarter to develop a new IMI during the dry period, risk for presence of IMI in the quarter at time of calving, or quarter-level risk for clinical mastitis between calving and 100 DIM (Arruda et al., 2013). However, producers are often interested not only in quarter-level bacteriological results, but also in biologically and economically relevant health and performance outcomes measured at the cow level. The objective of the current study was to compare the efficacy of SP, QT, and TM, when considering early lactation cow-level outcomes including 305-d mature-equivalent $(305 \mathrm{ME})$ milk production, LS, risk for the cow experiencing a clinical mastitis event, risk for leaving the herd, and risk for pregnancy in the first 100 DIM. Our hypothesis was that no difference would exist between these 3 DCT treatments when evaluating cow-level health and performance measures between calving and 100 DIM.

\section{MATERIALS AND METHODS}

\section{Herd Selection}

A randomized noninferiority clinical trial was conducted under approval of the University of Minnesota Institutional Animal Care and Use Committee (Saint Paul) between February 2011 and November 2011, using a convenience sample of 6 commercial dairy herds located in California $(n=2)$, Iowa $(n=1)$, Minnesota $(\mathrm{n}=1)$, and Wisconsin $(\mathrm{n}=2)$. Herd enrollment criteria and a description of study herds are available in a prior companion manuscript (Arruda et al., 2013).

\section{Cow Enrollment, Follow-Up, and Data Collection}

Cow enrollment was conducted weekly by trained university technicians. On the day of dry-off each week, cows were identified in the parlor and visually assessed for BCS, lameness, and clinical mastitis. Cow enrollment (inclusion) criteria at dry-off, the process used for randomized assignment to treatment with 1 of the 3 DCT products (QT, SP, or TM) at dry-off, and the procedures used for quarter-level milk sampling and bacteriological culture results at dry-off and after calving were previously reported (Arruda et al., 2013). Briefly, aseptic milk samples for bacteriological culture were collected from each quarter immediately before the last milking at dry-off, and again at 0 to 6 and 7 to 13 DIM. Immediately after the final milking, all 4 quarters were scrubbed with alcohol-soaked gauze and infused with the assigned DCT treatment and all 4 quarters massaged. An internal teat sealant (Orbeseal; Zoetis 
Animal Health) was then infused (used in all 6 herds), the teats postdipped with a disinfectant teat dip, and the cow then moved into the farm's dry cow facility for the duration of the dry period. Calving dates, clinical mastitis event dates, insemination dates that resulted in a pregnancy before 100 DIM, and culling and death event dates occurring before 100 DIM were recorded by farm staff using an on-farm electronic record-keeping system (DairyComp305; Valley Agricultural Software, Tulare, CA). The DairyComp305 software was also used to capture electronic DHIA test-day records occurring between calving and 100 DIM. Test-day measures of LS and 305ME milk production were included in these records, whereby LS was derived from a logarithmic transformation of the SCC (cells $/ \mathrm{mL}$ ), ranging from 0 to 9 , and whereby $305 \mathrm{ME}$ corresponds to an estimate of the projected lactation milk production $(\mathrm{kg})$, as calculated on a 305-d basis after adjusting for DIM on test day, milk frequency, season of calving, geographical location of the herd, and age (DHIA, 2012).

\section{Statistical Analysis}

Sample Size Calculations. The primary outcome used for a priori sample size calculations for this study was quarter-level risk for a microbiological cure during the dry period. Sample size calculations were based on a noninferiority study design, with a $10 \%$ maximum difference in cure rate required to declare noninferiority. A total of 339 cows (1,356 quarters) per group were estimated to be required to demonstrate noninferiority, assuming $\alpha=0.025$ and a power of $80 \%, 10 \%$ losses to follow-up, and that $30 \%$ of the quarters would be infected at dry-off and, therefore, at risk for a cure (noninferiority tests for 2 proportions; Pass 2008; NCSS LLC, Kaysville, UT).

Descriptive Statistics. All statistical analyses were conducted at the cow level using SAS (version 9.2; SAS Institute Inc., Cary, NC). Initially, descriptive statistics and plots were generated for exploratory data analysis, and basic diagnostic techniques were used to evaluate variables for normality, collinearity among independent variables and the presence of outliers. A chi-squared test and ANOVA was used to compare baseline (enrollment) characteristics of cows assigned to the 3 DCT treatment groups, including dry period length, parity, previous LS at the last DHIA test before dry-off, and previous-lactation milk production $(\mathrm{kg})$.

Effect of Treatment on LS and 305ME Milk Production. The effect of treatment on the 2 continuous dependent variables examined (305ME and LS) were analyzed by a mixed linear model (PROC MIXED), and using the cow's 305ME milk production or LS measure from the last DHIA test day before 100
DIM. In both models, region was included as a fixed effect (forced) and herd was included as random effect to account for the clustering effects of herds within region and cows within herd. In addition to DCT treatment group (forced), additional explanatory variables offered to these models included DIM on test day, parity, previous-lactation LS, previous-lactation total milk production $(\mathrm{kg})$, and dry period length (d). The variables describing DIM on test day, previous-lactation LS, previous-lactation total milk production, and dry period length were offered as continuous variables, whereas cow parity was dichotomized in 2 categories: second parity or third-and-greater parities. Univariate analysis was initially conducted to evaluate the relationship between each of the aforementioned explanatory variables and the dependent variable of interest. Variables significant at $P<0.2$ in univariate analysis were carried forward to offer into the full model. Nonsignificant variables were then removed from the model using a backward stepwise approach, with final significance declared at $P<0.05$. A variable was considered a confounder and retained in the final model if its inclusion in the model changed the estimate of the effect of the DCT treatment group on the dependent variable by $20 \%$ or greater. First-order interactions between DCT treatment group and all other significant main effects terms were tested and included in the model if significant. Finally, quadratic and cubic terms for significant continuous terms were offered to the final model and kept, if significant. Models were compared during the model-building process using the -2 log-likelihood statistic, and model fit was evaluated by plotting marginal and conditional residuals.

Effect of Treatment on Risk for Clinical Mastitis, Leaving the Herd, and Pregnancy by 100 DIM. Cox proportional hazards regression (PROC PHREG) was used to describe the effect of DCT treatment group on the survival distribution function for cows experiencing each of the following 3 time-to-event outcomes: (1) cow-level risk for the first case of clinical mastitis, (2) risk of leaving the herd due to culling or death, and (3) risk for pregnancy during the first 100 DIM. Cows were considered to be at risk for these events between calving and 100 DIM, with the failure date defined as the date when the cow was first reported to experience the outcome of interest. Cows not reported to experience the outcome were classified either as left censored at the cow's culling or death date, if before 100 DIM (for models predicting risk for clinical mastitis and risk for pregnancy), or right censored at 100 DIM if still in the herd at that time (for all 3 models). In addition to DCT treatment group (forced), additional explanatory variables offered to these 3 models included region (forced), parity, previous-lactation LS, previous-lacta- 
tion total milk production $(\mathrm{kg})$, and dry period length (d). Clustering of cows at the herd level was controlled for using the COVSANDWICH statement. Models were compared during the model-building process using the -2 log-likelihood statistic, and final model fit was assessed by plotting the deviance residuals.

\section{RESULTS AND DISCUSSION}

To our knowledge, this is the first multi-herd, multistate randomized noninferiority clinical trial conducted to compare the efficacy of 3 commonly used DCT preparations as related to multiple cow health and performance outcomes in US dairy herds, including measures of udder health, milk production, survival in the herd, and reproductive performance in the first 100 DIM. One very recent study did compare the efficacy of 2 DCT products (QT and SP) in 2 Florida dairy herds as related to risk for clinical mastitis and risk for high LS in the first 60 DIM (Pinedo et al., 2012). Other comparative DCT efficacy studies are few in number and have typically reported only quarter-level outcomes, such as microbiological cure and prevention of IMI during the dry period, but did not address long-term cow-level outcomes (e.g., McDougall, 2010) and (or) were conducted in other countries using DCT products not commercially available to US dairy producers (e.g., McDougall, 2010; Bradley et al., 2011). Strengths of the current study include the number of herds enrolled from different states and regions, and therefore the inclusion of different climates, potentially different mastitis pathogen profiles, and different dry cow housing and management strategies (previously described in Arruda et al., 2013). Also, bulk tank SCC were similar for the 6 study herds (242,170 cells/ $\mathrm{mL}$ ) compared with the average reported for US dairy herds ( 250,167 cells/mL; USDA-NAHMS, 2007). Despite these strengths, study herds were larger and had higher milk production (lactating cows $=2,230$; rolling herd average $=12,360 \mathrm{~kg}$ ) compared with the average reported for US dairy herds (lactating cows $=$ 167; annual milk per cow $=9,050 \mathrm{~kg}$; USDA-NAHMS, 2007). All study herds used an internal teat sealant at dry-off and had a commercial coliform mastitis vaccine incorporated into the vaccination program.

A total of 1,091 cows were enrolled into the study at dry-off (QT: $\mathrm{n}=373$, SP: $\mathrm{n}=349$, and TM: $\mathrm{n}=$ 369). A total of 27 of these animals either died or were culled during the dry period (QT: $\mathrm{n}=10, \mathrm{SP}: \mathrm{n}=10$, and TM: $\mathrm{n}=7$ ); therefore, a total of 1,064 cows calved and were considered in the current analysis of health and performance outcomes evaluated between calving and 100 DIM. The 3 treatment groups did not differ at baseline (dry-off) regarding the following descriptive parameters (overall mean $\pm \mathrm{SD}$ ): parity $(2.9 \pm 1.2)$, previous LS at last DHIA test before dry-off (3.0 \pm 1.6), previous-lactation total milk yield $(12,551 \pm 3,392$ $\mathrm{kg})$, and dry period length $(54.2 \pm 11.5 \mathrm{~d})$ at dry-off (Table 1).

\section{Effect of Treatment on LS}

A total of 1,008 cow records were included in the analysis of effect of DCT on LS. The overall unadjusted average LS was 1.8 (Table 2), with no effect of DCT treatment on LS at the last DHIA test day before 100 DIM (adjusted mean LS: QT $=1.8, \mathrm{SP}=1.9$, and $\mathrm{TM}$ $=1.6 ; P=0.21$; Table 3$)$. Other significant covariates retained in the final model included region $(P<0.01)$, parity $(P<0.01)$, and previous-lactation LS $(P<0.01$; Table 3).

The finding of no effect of DCT treatment on LS was consistent with the fact that previous analysis found no effect of DCT treatment on quarter-level risk for presence of IMI after calving (Arruda et al., 2013). This finding conflicts with a recent study conducted on 2 Florida dairy herds, which reported that cows treated with SP had significantly lower odds (odds ratio = 0.51) of having an elevated SCC (LS $\geq 4.5$ ) within 30 $\mathrm{d}$ after calving (first DHIA test) compared with cows

Table 1. Unadjusted average (SD) baseline characteristics for study cows by treatment group

\begin{tabular}{|c|c|c|c|c|}
\hline Item & \multicolumn{3}{|c|}{ Treatment $^{1}$} & Overall \\
\hline Number of cows enrolled & 373 & 349 & 369 & 1,091 \\
\hline Parity & $2.9(1.2)$ & $2.9(1.2)$ & $2.9(1.3)$ & $2.9(1.2)$ \\
\hline Previous linear score $^{2}$ & $2.9(1.6)$ & $2.9(1.6)$ & $3.1(1.6)$ & $3.0(1.6)$ \\
\hline Previous-lactation milk yield (kg) & $12,577(3,162)$ & $12,648(3,755)$ & $12,435(3,256)$ & $12,551(3,392)$ \\
\hline
\end{tabular}


Table 2. Unadjusted average (SD) 305-d mature-equivalent (305ME) milk production, linear score, proportion of cows experiencing a clinical mastitis event, proportion of cows culled or dead, and proportion of cows pregnant between calving and 100 DIM, by dry cow therapy treatment group and overall, at the cow level

\begin{tabular}{lcccc}
\hline & \multicolumn{4}{c}{ Treatment $^{1}$} \\
\cline { 2 - 4 } Variable & QT & SP & TM & Total \\
\hline 305 ME milk production $(\mathrm{kg})$ & $11,924(1,502)$ & $11,722(1,697)$ & $11,890(1,511)$ & $11,848(1,570)$ \\
$\mathrm{n}^{2}$ & 345 & 322 & 341 & 1,008 \\
Linear score & $1.8(2.2)$ & $2.0(2.1)$ & $1.7(2.1)$ & $1.8(2.1)$ \\
$\mathrm{n}$ & 345 & 322 & 341 & 1,008 \\
Clinical mastitis (\%) & 14.8 & 12.7 & 15.0 & 14.2 \\
$\mathrm{n}$ & 359 & 338 & 361 & 1,058 \\
Culled or dead (\%) & 7.5 & 9.2 & 10.3 & 9.0 \\
$\mathrm{n}$ & 359 & 338 & 361 & 1,058 \\
Pregnant $(\%)$ & 31.5 & 26.1 & 26.9 & 28.2 \\
$\mathrm{n}$ & 359 & 337 & 361 & 1,057 \\
\hline
\end{tabular}

${ }^{1} \mathrm{QT}=$ Quartermaster $(1,000,000 \mathrm{IU}$ of procaine penicillin $\mathrm{G}$ and $1 \mathrm{~g}$ of dihydrostreptomycin; Zoetis Animal Health, Madison, NJ); SP = Spectramast DC (500 mg of ceftiofur hydrochloride; Zoetis Animal Health); TM = ToMorrow Dry Cow (300 mg of cephapirin benzathine; Boehringer Ingelheim Vetmedica Inc., St Joseph, MO).

${ }^{2} \mathrm{n}=$ total number of observations.

treated with QT (Pinedo et al., 2012). In that study, cows treated with SP also had significant reduced odds (odds ratio $=0.52$ ) of having an elevated SCC within $60 \mathrm{~d}$ after calving (second DHIA test) compared with cows treated with QT. Unfortunately, those authors did not report group-specific LS measures or group-specific proportions of cows with an elevated LS. As such, the current authors cannot make direct comparisons of the LS results between the aforementioned and the current study. As an aside, the current authors did perform a separate repeated-measures analysis of all LS measures recorded on all DHIA test days between calving and 100 DIM, and found no effect of DCT treatment at any test-day time point (results not shown). Notable differences exist in design and approach to analysis, either of which may explain the differences in findings between the 2 studies. For example, the Pinedo et al. (2012) study was limited to 2 Florida dairy herds and had a shorter period of follow-up (60 d), whereas the current study included 6 herds from Minnesota, Wisconsin, Iowa, and California and a 100-DIM follow-up period. Differences in herd numbers and regions could contribute to between-study differences in herd management practices, herd-specific mastitis pathogen profiles, risk for IMI during the dry period, risk for clinical mastitis in early lactation, and LS in early lactation.

Table 3. Final multivariate linear regression model for the analysis of effect of dry cow therapy treatment on linear score at the last DHIA test before 100 DIM, at the cow level

\begin{tabular}{|c|c|c|c|c|c|c|}
\hline \multirow[b]{2}{*}{ Variable } & \multirow[b]{2}{*}{ LSM (SE) } & \multirow[b]{2}{*}{ Coefficient } & \multirow[b]{2}{*}{$\mathrm{SE}$} & \multicolumn{2}{|c|}{$95 \% \mathrm{CI}^{1}$} & \multirow{2}{*}{$\begin{array}{l}\text { Type III } \\
P \text {-value }\end{array}$} \\
\hline & & & & LCL & UCL & \\
\hline Intercept & & 1.37 & 0.22 & & & \\
\hline \multicolumn{7}{|l|}{ Treatment $^{2}$} \\
\hline QT & $1.8(0.1)$ & 0.15 & 0.15 & -0.15 & 0.45 & 0.21 \\
\hline SP & $1.9(0.1)$ & 0.28 & 0.16 & -0.02 & 0.58 & \\
\hline \multirow{2}{*}{\multicolumn{7}{|c|}{ Region $^{3}$}} \\
\hline & & & & & & \\
\hline $\mathrm{CA}$ & $2.1(0.1)$ & 0.10 & 0.15 & -0.21 & 0.39 & $<0.01$ \\
\hline IA & $1.1(0.1)$ & -0.94 & 0.17 & -1.27 & -0.61 & \\
\hline $\mathrm{MN}$ & $2.0(0.1)$ & Referent & & & & \\
\hline Previous LS $^{4}$ & & 0.26 & 0.04 & 0.18 & 0.34 & $<0.01$ \\
\hline \multicolumn{7}{|l|}{ Parity } \\
\hline 2 & $1.6(0.1)$ & -0.43 & 0.14 & -0.70 & -0.17 & $<0.01$ \\
\hline$>2$ & $2.0(0.1)$ & Referent & & & & \\
\hline
\end{tabular}

${ }^{1} \mathrm{LCL}=$ lower confidence limit; UCL $=$ upper confidence limit.

${ }^{2} \mathrm{QT}=$ Quartermaster (1,000,000 IU of procaine penicillin $\mathrm{G}$ and $1 \mathrm{~g}$ of dihydrostreptomycin; Zoetis Animal Health, Madison, NJ); SP = Spectramast DC (500 mg of ceftiofur hydrochloride; Zoetis Animal Health). TM = ToMorrow Dry Cow (300 mg of cephapirin benzathine; Boehringer Ingelheim Vetmedica Inc., St Joseph, MO). ${ }^{3} \mathrm{CA}=$ California; IA = Iowa; $\mathrm{MN}=$ herds from both states of Minnesota and Wisconsin.

${ }^{4}$ Last linear score before dry-off. 


\section{Effect of Treatment on 305ME Milk Production}

Milk-production measures (305ME) from DHIA testday records were available for 1,008 cows. The mean DIM for the last test before 100 DIM was 76,76 , and 75 $\mathrm{d}$ for cows treated with QT, SP, and TM, respectively. The overall unadjusted average $305 \mathrm{ME}$ was $11,848 \mathrm{~kg}$ (Table 2). The final model showed no effect of DCT treatment on 305ME at the last DHIA test day before 100 DIM (adjusted mean 305ME: QT $=11,759 \mathrm{~kg}$, SP $=11,574 \mathrm{~kg}$, and $\mathrm{TM}=11,761 \mathrm{~kg} ; P=0.11$; Table 4). Other significant covariates retained in the final model included parity $(P<0.01)$, DIM on test day $(P$ $<0.01$ ), and previous-lactation total milk production $(P<0.01$; Table 4).

Given that the current study found no effect of DCT treatment on quarter-level risk for presence of IMI after calving (Arruda et al., 2013) and no effect on LS (previously described), then it is not surprising that the current analysis also found no effect of DCT treatment on $305 \mathrm{ME}$ milk production. The authors are not aware of other studies comparing the effect of North American commercially available DCT products on milk production in the subsequent lactation. One limitation of the analysis of the effect of treatment on LS and 305ME outcomes is that it was based on a single test-day measurement (i.e., last DHIA test before 100 DIM). However, prior repeated-measures analysis, which used all DHIA test-day data collected before 100 DIM, showed similar results (analysis not shown).

\section{Effect of Treatment on Risk for Experiencing a Clinical Mastitis Event Between Calving and 100 DIM}

A total of 1,058 cow records were used to analyze the effect of DCT treatment on cow-level risk for a clinical mastitis event between calving and 100 DIM. Six cow records were omitted due to missing previous-lactation LS information (QT: $\mathrm{n}=3$, SP: $\mathrm{n}=1$, and TM: $\mathrm{n}=$ 2 ). The overall crude incidence of clinical mastitis from calving to 100 DIM was $14.2 \%$ (Table 2), with no effect of DCT treatment on risk for a clinical mastitis event $(\mathrm{QT}=14.8 \%, \mathrm{SP}=12.7 \%$ and $\mathrm{TM}=15.0 \%, P=$ 0.80 ; Table 5). Other significant covariates retained in the final model included parity $(P<0.01)$, region $(P$ $<0.01)$ and previous-lactation LS $(P<0.01$; Table 5).

The incidence of clinical mastitis in the first 100 DIM observed in this study (14.2\%) is consistent with other studies of US dairy herds. One study conducted in 2 Florida dairy herds reported an overall clinical mastitis incidence of 7.4 and $10.1 \%$ during the first 30 and 60 DIM, respectively (Pinedo et al., 2012). Another study conducted in 2 New York dairy herds reported a lactational incidence for clinical mastitis of 19.6 and $28.8 \%$ for first and second-plus lactation cows, respectively, for one dairy, and 6.3 and $13.8 \%$ for first and secondplus lactation cows, respectively, for the other dairy (Wilson et al., 2004).

In the current study, no effect of DCT treatment was observed on risk for experiencing a clinical mastitis event between calving and 100 DIM. This is consistent

Table 4. Final multivariate linear regression model for the analysis of effect of dry cow therapy treatment on 305-d mature-equivalent (305ME) milk production $(\mathrm{kg})$ at the last test day before $100 \mathrm{DIM}$, at the cow level

\begin{tabular}{|c|c|c|c|c|c|c|}
\hline \multirow[b]{2}{*}{ Variable } & \multirow[b]{2}{*}{ LSM (SE) } & \multirow[b]{2}{*}{ Coefficient } & \multirow[b]{2}{*}{$\mathrm{SE}$} & \multicolumn{2}{|c|}{$95 \% \mathrm{CI}^{1}$} & \multirow{2}{*}{$\begin{array}{c}\text { Type III } \\
P \text {-value }\end{array}$} \\
\hline & & & & LCL & UCL & \\
\hline Intercept & & $9,537.77$ & 508.05 & & & \\
\hline \multicolumn{7}{|l|}{ Treatment $^{2}$} \\
\hline QT & 11,759 (324) & -1.49 & 100.05 & -193.58 & 190.61 & 0.11 \\
\hline SP & $11,574(325)$ & -187.15 & 101.86 & -382.72 & 102.28 & \\
\hline $\mathrm{TM}$ & 11,761 (324) & Referent & & & & \\
\hline \multicolumn{7}{|l|}{ Region $^{3}$} \\
\hline $\mathrm{CA}$ & $11,812(501)$ & -562.34 & 649.33 & $-1,809.05$ & -684.37 & 0.19 \\
\hline IA & $10,908(706)$ & $-1,466.95$ & 817.31 & $-3,036.19$ & 102.28 & \\
\hline $\mathrm{MN}$ & $12,374(412)$ & Referent & & & & \\
\hline DIM at test day ${ }^{4}$ & & 23.11 & 2.75 & 17.83 & 28.39 & $<0.01$ \\
\hline \multicolumn{7}{|l|}{ Parity } \\
\hline 2 & $11,996(322)$ & 595.41 & 88.84 & 424.84 & 765.98 & $<0.01$ \\
\hline$>2$ & $11,400(322)$ & Referent & & & & \\
\hline Previous milk ${ }^{5}$ & & 0.07 & 0.01 & 0.05 & 0.08 & $<0.01$ \\
\hline
\end{tabular}

${ }^{1} \mathrm{LCL}=$ lower confidence limit; UCL = upper confidence limit.

${ }^{2} \mathrm{QT}=$ Quartermaster (1,000,000 IU of procaine penicillin $\mathrm{G}$ and $1 \mathrm{~g}$ of dihydrostreptomycin; Zoetis Animal Health, Madison, NJ); SP = Spectramast DC (500 mg of ceftiofur hydrochloride; Zoetis Animal Health); TM = ToMorrow Dry Cow (300 mg of cephapirin benzathine; Boehringer Ingelheim Vetmedica Inc., St Joseph, MO). ${ }^{3} \mathrm{CA}=$ California; IA = Iowa; $\mathrm{MN}=$ herds from both states of Minnesota and Wisconsin.

${ }^{4}$ Days in milk at DHIA test day.

${ }^{5}$ Total milk produced in the previous lactation $(\mathrm{kg})$. 
Table 5. Final Cox proportional hazards regression model for the analysis of effect of dry cow therapy treatment on risk for a clinical mastitis event at the cow level between calving and 100 DIM

\begin{tabular}{|c|c|c|c|c|c|c|}
\hline \multirow[b]{2}{*}{ Variable } & \multirow[b]{2}{*}{ Coefficient } & \multirow[b]{2}{*}{$\mathrm{SE}$} & \multirow{2}{*}{$\begin{array}{l}\text { Hazard } \\
\text { ratio }^{1}\end{array}$} & \multicolumn{2}{|c|}{$95 \% \mathrm{CI}^{2}$} & \multirow[b]{2}{*}{$P$-value } \\
\hline & & & & LCL & UCL & \\
\hline \multicolumn{7}{|l|}{ Treatment $^{3}$} \\
\hline $\mathrm{QT}$ & 0.005 & 0.19 & 1.005 & 0.69 & 1.46 & 0.80 \\
\hline $\mathrm{SP}$ & -0.12 & 0.20 & 0.89 & 0.60 & 1.33 & \\
\hline \multirow{2}{*}{\multicolumn{7}{|c|}{ Region $^{4}$}} \\
\hline & & & & & & \\
\hline $\mathrm{CA}$ & -1.04 & 0.18 & 0.35 & 0.25 & 0.50 & $<0.01$ \\
\hline IA & -2.38 & 0.35 & 0.09 & 0.05 & 0.18 & \\
\hline $\mathrm{MN}$ & Referent & & 1.00 & & & \\
\hline Previous LS $^{5}$ & 0.21 & 0.05 & 1.23 & 1.13 & 1.34 & $<0.01$ \\
\hline \multicolumn{7}{|l|}{ Parity } \\
\hline 2 & -0.52 & 0.17 & 0.60 & 0.43 & 0.83 & $<0.01$ \\
\hline$>2$ & Referent & & 1.00 & & & \\
\hline
\end{tabular}

${ }^{1}$ Hazard of experiencing a clinical mastitis event.

${ }^{2}$ Confidence interval for the hazard ratio: lower (LCL) and upper (UCL) confidence limits.

${ }^{3} \mathrm{QT}=$ Quartermaster (1,000,000 IU of procaine penicillin $\mathrm{G}$ and $1 \mathrm{~g}$ of dihydrostreptomycin; Zoetis Animal Health, Madison, NJ). SP = Spectramast DC (500 mg of ceftiofur hydrochloride; Zoetis Animal Health); TM = ToMorrow Dry Cow (300 mg of cephapirin benzathine; Boehringer Ingelheim Vetmedica Inc., St Joseph, MO).

${ }^{4} \mathrm{CA}=$ California; IA = Iowa; MN = herds from both states of Minnesota and Wisconsin.

${ }^{5}$ Linear score at last DHIA test before dry-off.

with the fact that the same study found no effect of DCT on quarter-level risk for presence of IMI after calving (Arruda et al., 2013) and no effect on LS (previously described). However, this finding conflicts with results from a recent study reporting that cows treated with SP had 38 and $27 \%$ lower odds of experiencing a clinical case during the first 30 DIM and during the first 60 DIM, respectively, compared with cows treated with QT (Pinedo et al., 2012). Unfortunately, the latter study did not report treatment group-specific clinical mastitis incidence rates, precluding our ability to compare incidence rates between the 2 studies. As previously mentioned, between-study differences in geographic location, herd numbers, pathogen profile, duration of follow-up period, herd management characteristics, and approaches to data analysis may explain differences in results between the 2 studies.

\section{Effect of Treatment on Risk for Leaving the Herd Between Calving and 100 DIM}

A total of 1,064 cows records were used for the analysis of effect of treatment on risk for leaving the herd. The overall crude risk for leaving the herd by either culling or death was $9.0 \%$ (Table 2), with no effect of DCT treatment on risk for leaving the herd between calving and $100 \mathrm{DIM}(\mathrm{QT}=7.5 \%, \mathrm{SP}=9.2 \%$, and $\mathrm{TM}=10.3 \% ; P=0.55$; Table 6 ). Parity was the only significant covariate retained in the final model $(P<$ 0.01 ; Table 6 ). These findings are consistent with the fact that previous analyses have shown no effect of DCT treatment on risk for presence of IMI at calving
(Arruda et al., 2013), on LS before 100 DIM, on 305ME milk production before 100 DIM, or on risk for experiencing a quarter-level or cow-level clinical mastitis event between calving and 100 DIM.

\section{Effect of Treatment on Risk for Pregnancy by 100 DIM}

A total of 1,057 cow records were used for the analysis of the effect of treatment on risk for pregnancy between calving and 100 DIM. Seven cow records were omitted due to missing previous-lactation total milk production records (QT: $\mathrm{n}=3$, SP: $\mathrm{n}=2$, and TM: $\mathrm{n}=2$ ). The overall proportion of cows pregnant by 100 DIM was $28.2 \%$ (Table 2), with final analysis showing no effect of DCT treatment on risk or time to pregnancy $(\mathrm{QT}=31.5 \%, \mathrm{SP}=26.1 \%$, and $\mathrm{TM}=26.9 \% ; P=$ 0.26 ; Table 7). Other significant covariates retained in the final model included previous-lactation total milk production $(P=0.01)$, dry period length $(P=0.04)$, and region $(P<0.01$; Table 7$)$. These findings are consistent with the fact that previous analyses have shown no effect of DCT treatment on risk for presence of IMI at calving (Arruda et al., 2013), LS before 100 DIM, 305ME milk production before 100 DIM, or risk for experiencing a quarter-level or cow-level clinical mastitis event between calving and 100 DIM.

\section{Secondary Findings}

Previous-Lactation $L S$. The current study found positive associations between LS before dry-off and both 
Table 6. Final Cox proportional hazards regression model for the analysis of effect of dry cow therapy treatment on risk for leaving the herd (culling or death) between calving and 100 DIM

\begin{tabular}{|c|c|c|c|c|c|c|}
\hline \multirow[b]{2}{*}{ Variable } & \multirow[b]{2}{*}{ Coefficient } & \multirow[b]{2}{*}{$\mathrm{SE}$} & \multirow{2}{*}{$\begin{array}{c}\text { Hazard } \\
\text { ratio }^{1}\end{array}$} & \multicolumn{2}{|c|}{$95 \% \mathrm{CI}^{2}$} & \multirow[b]{2}{*}{$P$-value } \\
\hline & & & & LCL & UCL & \\
\hline \multicolumn{7}{|c|}{ Treatment $^{3}$} \\
\hline $\mathrm{QT}$ & -0.26 & 0.24 & 0.77 & 0.46 & 1.23 & 0.55 \\
\hline SP & -0.15 & 0.24 & 0.86 & 0.56 & 1.47 & \\
\hline TM & Referent & & 1.00 & & & \\
\hline \multicolumn{7}{|l|}{ Region ${ }^{4}$} \\
\hline $\mathrm{CA}$ & 0.28 & 0.24 & 1.33 & 0.82 & 2.14 & 0.48 \\
\hline IA & 0.24 & 0.26 & 1.28 & 0.60 & 1.76 & \\
\hline $\mathrm{MN}$ & Referent & & 1.00 & & & \\
\hline \multicolumn{7}{|l|}{ Parity } \\
\hline 2 & -1.09 & 0.24 & 0.34 & 0.23 & 0.59 & $<0.01$ \\
\hline$>2$ & Referent & & 1.00 & & & \\
\hline
\end{tabular}

${ }^{1}$ Hazard of experiencing a clinical mastitis event.

${ }^{2}$ Confidence interval for the hazard ratio: lower (LCL) and upper (UCL) confidence limits.

${ }^{3} \mathrm{QT}=$ Quartermaster $(1,000,000 \mathrm{IU}$ of procaine penicillin $\mathrm{G}$ and $1 \mathrm{~g}$ of dihydrostreptomycin; Zoetis Animal Health, Madison, NJ); SP = Spectramast DC (500 mg of ceftiofur hydrochloride; Zoetis Animal Health); TM = ToMorrow Dry Cow (300 mg of cephapirin benzathine; Boehringer Ingelheim Vetmedica Inc., St Joseph, MO).

${ }^{4} \mathrm{CA}=$ California; $\mathrm{IA}=$ Iowa; $\mathrm{MN}=$ herds from both states of Minnesota and Wisconsin.

LS in the subsequent lactation and risk for a clinical mastitis episode between calving and 100 DIM. These findings agree with a study by Pinedo et al. (2012), which reported that high average LS in the previous lactation was associated with an increase in the odds for clinical mastitis up to $60 \mathrm{~d}$ after calving, and an increase in the odds for a high LS at 30 and 60 DIM. Similar findings were reported in a study by Pantoja et al. (2009), wherein cows with $\mathrm{SCC} \geq 200,000$ cells/ $\mathrm{mL}$ across the dry period had a greater risk of being subclinically infected with a major pathogen at 30 DIM and were at greater risk of experiencing a clinical mas- titis event during the first 120 DIM, compared with cows with a previous SCC $<200,000$ cells $/ \mathrm{mL}$. Multiple explanations possibly exist for this relationship. An elevated LS before dry-off is an indirect indicator of presence of IMI. If some of these IMI failed to cure during the dry period, then their persistence in the gland after calving would be expected to be associated with an increased risk for clinical mastitis (Green et al., 2007) and elevated LS in the next lactation. Alternately, these quarters or cows might have some intrinsic characteristics (e.g., impaired immunity) putting them at increased risk for experiencing a new IMI between

Table 7. Final Cox proportional hazards regression model for the analysis of effect of dry cow therapy treatment on risk for pregnancy between calving and 100 DIM

\begin{tabular}{|c|c|c|c|c|c|c|}
\hline \multirow[b]{2}{*}{ Variable } & \multirow[b]{2}{*}{ Coefficient } & \multirow[b]{2}{*}{$\mathrm{SE}$} & \multirow[b]{2}{*}{$\begin{array}{l}\text { Hazard } \\
\text { ratio }^{1}\end{array}$} & \multicolumn{2}{|c|}{$95 \% \mathrm{CI}^{2}$} & \multirow[b]{2}{*}{$P$-value } \\
\hline & & & & LCL & UCL & \\
\hline \multicolumn{7}{|l|}{ Treatment $^{3}$} \\
\hline QT & 0.19 & 0.14 & 1.21 & 0.92 & 1.58 & 0.26 \\
\hline SP & -0.02 & 0.15 & 0.98 & 0.74 & 1.31 & \\
\hline TM & Referent & & 1.00 & & & \\
\hline \multicolumn{7}{|l|}{ Region $^{4}$} \\
\hline $\mathrm{CA}$ & -0.33 & 0.16 & 0.72 & 0.53 & 0.98 & $<0.01$ \\
\hline IA & 0.35 & 0.14 & 1.42 & 1.08 & 1.88 & \\
\hline $\mathrm{MN}$ & Referent & & 1.00 & & & \\
\hline Previous milk ${ }^{5}$ & -0.00005 & 0.00002 & 0.9999 & 0.9999 & 0.9999 & 0.01 \\
\hline Dry period $(d)$ & 0.01 & 0.005 & 1.01 & 1.001 & 1.02 & 0.04 \\
\hline
\end{tabular}

${ }^{1}$ Hazard of experiencing a clinical mastitis event.

${ }^{2}$ Confidence interval for the hazard ratio: lower (LCL) and upper (UCL) confidence limits.

${ }^{3} \mathrm{QT}=$ Quartermaster (1,000,000 IU of procaine penicillin $\mathrm{G}$ and $1 \mathrm{~g}$ of dihydrostreptomycin; Zoetis Animal Health, Madison, NJ); SP = Spectramast DC (500 mg of ceftiofur hydrochloride; Zoetis Animal Health); TM = ToMorrow Dry Cow (300 mg of cephapirin benzathine; Boehringer Ingelheim Vetmedica Inc., St Joseph, MO). ${ }^{4} \mathrm{CA}=$ California; IA = Iowa; $\mathrm{MN}$ = herds from both states of Minnesota and Wisconsin.

${ }^{5}$ Total milk produced in the previous lactation $(\mathrm{kg})$. 
dry-off and the subsequent calving or in the subsequent lactation.

Parity. In the current study, parity was positively associated with LS, risk for clinical mastitis, and risk for leaving the herd between calving and 100 DIM. A positive association between parity and risk for acquiring new IMI during the dry period has been previously reported (Dingwell et al., 2004), as well as a positive association between parity and risk for clinical mastitis (Green et al., 2007; Pantoja et al., 2009), and a positive association between parity and culling risk (Hadley et al., 2006). The fact that older cows may have disrupted natural defenses could explain, in part, some of the associations observed in the current study (Green et al., 2007).

DIM at DHIA Test Day. In the current study, DIM at DHIA test day was positively associated with 305ME milk production. Even though the 305ME projection equation is designed to adjust for DIM on test day (DHIA, 2012), it is possible that the DIM correction factor used in the equation is imperfect, resulting in underestimating milk production when measured earlier in the lactation. Additionally, milk production might genuinely increase after cows are exposed to production-enhancing management strategies including the use of recombinant bovine somatotropin (rBST; Posilac; Elanco Animal Health Co., Indianapolis, IN), normally implemented between 57 and 70 DIM. In the current study, 2 herds did not use rBST, 3 herds implemented the use of rBST between 56 and 70 DIM, and 1 herd implemented the use of rBST after 90 DIM.

Previous-Lactation Milk Production. Previouslactation milk production $(\mathrm{kg})$ was positively associated with $305 \mathrm{ME}$ milk production in the current lactation but negatively associated with risk for pregnancy by 100 DIM. Data on the association between milk production and pregnancy rates are conflicting (Le Blanc, 2010), but a possible explanation could be that high-producing cows may spend more energy on milk production and less energy on preparation of the reproductive tract to initiate ovarian cyclicity and to support a new pregnancy (Butler and Smith, 1989).

Dry Period Length. Dry period length was positively associated with risk for pregnancy by 100 DIM. A biological explanation for this relationship is not immediately forthcoming, and results of earlier studies examining this relationship have been conflicting. Watters et al. (2009) reported reduced median days to first postpartum ovulation and a tendency for improved proportion of cows pregnant by 70 DIM for cows assigned to a shortened dry period of $34 \mathrm{~d}$ compared with a traditional dry period of $55 \mathrm{~d}$. Conversely, Pezeshki et al. (2007) reported that, although days open was somewhat lower in cows with a 56-d dry period than a 42 -d dry period, first-service conception rate was greater in multiparous cows with a 35-d dry period compared with longer dry periods. The authors of the current study hypothesize that excessively short dry periods may be associated with an insufficient transition period and weight loss, resulting in a negative energy balance, which may then be associated with delayed resumption of normal ovarian cyclicity (Butler and Smith, 1989).

\section{CONCLUSIONS}

The current study found no difference in efficacy among 3 commercially available DCT treatments when considering cow health and performance measures during the first 100 DIM. Specifically, no effect of treatment was observed on risk for experiencing a clinical mastitis event, risk for leaving the herd due to culling or death, or risk for pregnancy from calving to 100 DIM. No effect of DCT treatment was observed on 305ME milk production and LS measured on the last DHIA test day before 100 DIM. These results were expected, as prior analysis had shown no difference among the 3 DCT treatments when considering quarter-level udder health outcomes, including risk for a bacteriological cure during the dry period, risk for acquiring a new IMI during the dry period, risk for presence of IMI postcalving, or risk for a quarter to experience a clinical mastitis episode during the first 100 DIM (Arruda et al., 2013). Dairy producers should potentially put aside questions about differences in DCT product efficacy, and instead make herd-specific decisions selecting among these 3 DCT products based on other important considerations, such as required dry period length, milk withhold time postcalving, or product cost.

\section{ACKNOWLEDGMENTS}

Financial support for this study was provided by Boehringer Ingelheim Vetmedica Inc. (St. Joseph, MO) and the College of Veterinary Medicine from the University of Minnesota (St. Paul). We thank the participating farm owners, staff, and study technicians who assisted with cow enrollment and sampling activities.

\section{REFERENCES}

Arruda, A. G., S. Godden, P. Rapnicki, P. Gorden, L. Timms, S. Aly, J. Champagne, and T. Lehenbauer. 2013. Randomized noninferiority clinical trial evaluating 3 commercial dry cow mastitis preparations: I. Quarter-level outcomes. J. Dairy Sci. 96:4419-4435.

Bradley, A. J., J. E. Breen, B. Payne, and M. J. Green. 2011. A comparison of broad-spectrum and narrow-spectrum dry cow therapy used alone and in combination with a teat sealant. J. Dairy Sci. 94:692-704. 
Butler, W. R., and R. D. Smith. 1989. Interrelationships between energy balance and postpartum reproductive function in dairy cattle. J. Dairy Sci. 72:767-783.

Cook, N. B., D. Pionek, and P. Sharp. 2005. An assessment of the benefits of Orbeseal when used in combination with dry cow therapy in three commercial dairy herds. Bovine Pract. 39:83-94.

DHIA. 2012. DHI Glossary. Accessed Oct. 10, 2012. http://www.drms. org/PDF/materials/glossary.pdf.

Dingwell, R. T., K. E. Leslie, Y. H. Schukken, J. M. Sargeant, L. L. Timms, T. F. Duffield, G. P. Keefe, D. F. Kelton, K. D. Lissemore, and J. Conklin. 2004. Association of cow and quarter-level factors at drying-off with new intramammary infections during the dry period. Prev. Vet. Med. 63:75-89.

Dohoo, I. R., and S. W. Martin. 1984. Disease, production and culling in Holstein-Friesian cows: IV. Effects of disease on production. Prev. Vet. Med. 2:755-770.

Godden, S., P. Rapnicki, S. Stewart, J. Fetrow, A. Johnson, R. Bey, and R. Farnsworth. 2003. Effectiveness of an internal teat seal in the prevention of new intramammary infections during the dry and early-lactation periods in dairy cows when used with a dry cow intramammary antibiotic. J. Dairy Sci. 86:3899-3911.

Green, M. J., A. J. Bradley, G. F. Medley, and W. J. Browne. 2007. Cow, farm, and management factors during the dry period that determine the rate of clinical mastitis after calving. J. Dairy Sci. 90:3764-3776

Green, M. J., L. E. Green, A. J. Bradley, P. R. Burton, Y. H. Schukken, and G. F. Medley. 2005. Prevalence and associations between bacterial isolates from dry mammary glands of dairy cows. Vet. Rec. 156:71-77.

Hadley, G. L., C. A. Wolf, and S. B. Harsh. 2006. Dairy cattle culling patterns, explanations, and implications. J. Dairy Sci. 89:22862296.

LeBlanc, S. 2010. Assessing the association of the level of milk production with reproductive performance in dairy cattle. J. Reprod. Dev. 56:S1-S7.

McDougall, S. 2010. A randomised, non-inferiority trial of a new cephalonium dry-cow therapy. N. Z. Vet. J. 58:45-58.

Milian-Suazo, F. H. N. Erb, and R. D. Smith. 1989. Risk factors for reason-specific culling of dairy cows. Prev. Vet. Med. 7:19-29.
NMC (National Mastitis Council). 1999. Laboratory Handbook on Bovine Mastitis. NMC, Madison, WI

Oliver, S. P., and B. A. Mitchell. 1983. Susceptibility of bovine mammary gland to infections during the dry period. J. Dairy Sci. 66:1162-1166.

Pantoja, J. C., C. Hulland, and P. L. Ruegg. 2009. Dynamics of somatic cell counts and intramammary infections across the dry period. Prev. Vet. Med. 90:43-54.

Pezeshki, A., J. Mehrzad, G. R. Ghorbani, H. R. Rahmani, R. J. Collier, and C. Burvenich. 2007. Effects of short dry periods on performance and metabolic status in Holstein dairy cows. J. Dairy Sci. 90:5531-5541.

Pinedo, P. J., C. Fleming, and C. A. Risco. 2012. Events occurring during the previous lactation, the dry period, and the peripartum as risk factors for early lactation mastitis in cows receiving 2 different intramammary dry cow therapies. J. Dairy Sci. 95:7015-7026.

Schrick, F. N., M. E. Hockett, A. M. Saxton, M. J. Lewis, H. H. Dowlen, and S. P. Oliver. 2001. Influence of subclinical mastitis during early lactation on reproductive parameters. J. Dairy Sci. 84:1407-1412.

USDA-APHIS (US Department of Agriculture Animal and Plant Health Inspection Service). 2011. Determining U.S. milk quality using bulk-tank somatic cell counts, 2011. Accessed Oct. 26 2012. http://www.aphis.usda.gov/animal_health/nahms/dairy/ downloads/dairy_monitoring/BTSCC_2011infosheet.pdf.

USDA-NAHMS (US Department of Agriculture National Animal Health Monitoring System). 2007. Dairy 2007. Part II: Changes in the U.S. Dairy Cattle Industry, 1991. Accessed May 6, 2013. http://www.aphis.usda.gov/animal_health/nahms/dairy/ downloads/dairy07/Dairy07_dr_PartII.pdf.

Watters, R. D., M. C. Wiltbank, J. N. Guenther, A. E. Brickner, R. R. Rastani, P. M. Fricke, and R. R. Grummer. 2009. Effect of dry period length on reproduction during the subsequent lactation. J. Dairy Sci. 92:3081-3090.

Wilson, D. J., R. N. González, J. Hertl, H. F. Schulte, G. J. Bennett, Y. H. Schukken, and Y. T. Gröhn. 2004. Effect of clinical mastitis on the lactation curve: A mixed model estimation using daily milk weights. J. Dairy Sci. 87:2073-2084. 